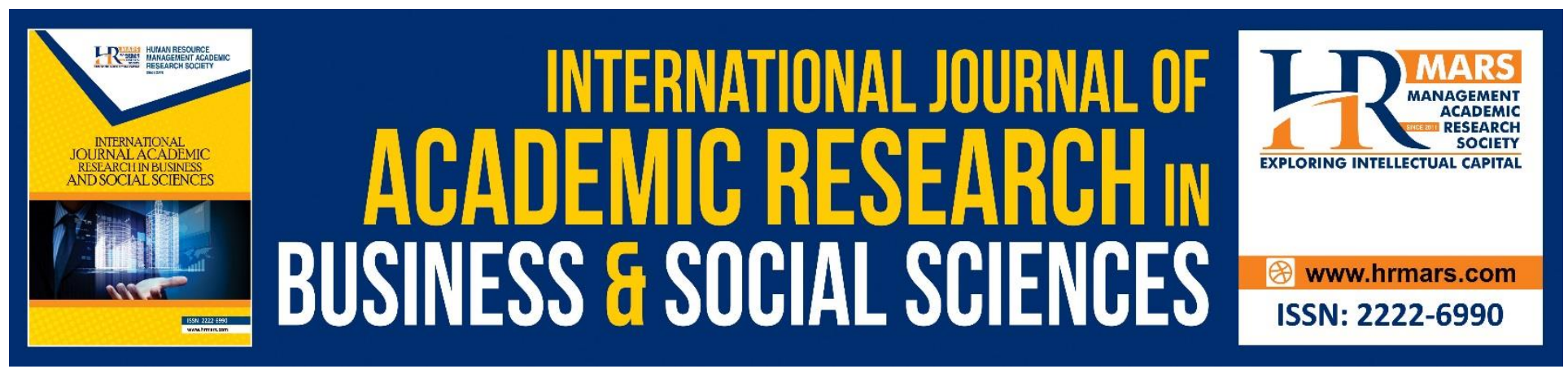

\title{
Revenue beyond Oil Reliance: Can Nigeria Leverage Non-oil Tax Revenue for Inclusive and Pro-poor Growth?
}

\author{
Joel E. Owuru, Olabode E. Olabisi
}

To Link this Article: http://dx.doi.org/10.6007/IJARBSS/v10-i9/7722

DOI:10.6007/IJARBSS/v10-i9/7722

Received: 09 June 2020, Revised: 10 July 2020, Accepted: 16 August 2020

Published Online: 17 September 2020

In-Text Citation: (Owuru, Olabisi, 2020)

To Cite this Article: Owuru, J. E., Olabisi, O. E. (2020). Revenue beyond Oil Reliance: Can Nigeria Leverage Non-oil Tax Revenue for Inclusive and Pro-poor Growth. International Journal of Academic Research in Business and Social Sciences. 10(9), 199-212.

Copyright: (c) 2020 The Author(s)

Published by Human Resource Management Academic Research Society (www.hrmars.com)

This article is published under the Creative Commons Attribution (CC BY 4.0) license. Anyone may reproduce, distribute, translate and create derivative works of this article (for both commercial and non-commercial purposes), subject to full attribution to the original publication and authors. The full terms of this license may be seen at: http://creativecommons.org/licences/by/4.0/legalcode

Vol. 10, No. 9, 2020, Pg. 199 - 212

http://hrmars.com/index.php/pages/detail/IJARBSS

JOURNAL HOMEPAGE

Full Terms \& Conditions of access and use can be found at http://hrmars.com/index.php/pages/detail/publication-ethics 


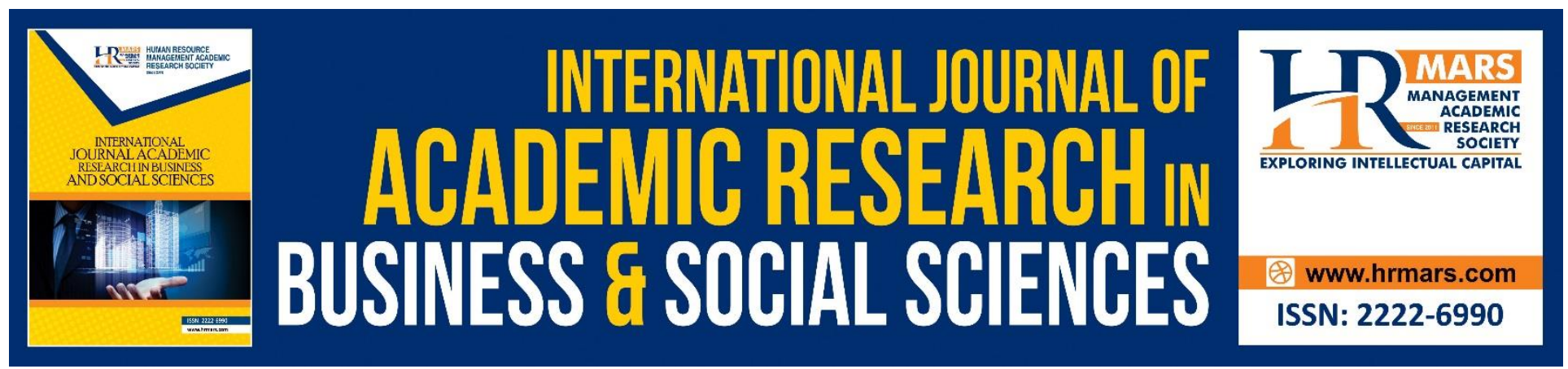

\title{
Revenue beyond Oil Reliance: Can Nigeria Leverage Non-oil Tax Revenue for Inclusive and Pro-poor Growth?
}

\author{
Joel E. Owuru \\ Department of Economics, Faculty of Humanities, Management, and Social Sciences, Augustine \\ University, Ilara-Epe, Lagos State, Nigeria \\ Email: joel.owuru@augustineuniversity.edu.ng \\ Olabode E. Olabisi \\ Department of Economics, Faculty of Social and Management Sciences, Elizade University, Ilara- \\ Mokin, Ondo State, Nigeria.
}

\begin{abstract}
The main aim of this study was to empirically examine the possibility for Nigeria to leverage non-oil tax revenue for inclusive and pro-poor growth. This is done through an analysis of quarterly data on oil tax revenue and non-oil tax revenue factors spanning 2011-2016. The study adopts Fully Modified Ordinary Least Square (FMOLS) estimation strategy in order to make inferences. The results of our analysis show that non-oil tax revenue has a positive contribution to inclusive growth in Nigeria than oil revenue. Based on this empirical evidence, non-oil tax revenue has the potential of aiding sustainable inclusive growth in Nigeria; hence the economy of Nigeria should be diversified intensively to increasingly harness the potential opportunities of the real sectors where non-oil tax revenue is generated in order to attain sustainable inclusive and pro-poor growth.
\end{abstract}

Keywords: Oil Tax Revenue, Non-Oil Tax Revenue, Inclusive (pro-poor) growth, and FMOLS

\section{Introduction}

In order to fulfill the two sides of the social contract between the state and its citizens, every nation or economy in the world should be typically responsible in devising a medium through which sustainable economic development can be achieved. Hence, government is expected to provide the citizens with the needed social amenities that would enhance the welfare of the people through proper utilization of the tax payers' monies. In line with the opinion of Wong (2004), it is not a deniable fact that availability of certain infrastructural facilities required to accelerate various economic activities underscores the process of growth and development of an economy. In fact, among the various sources of revenue that government sought for to be able to spin vital deliverables 
INTERNATIONAL JOURNAL OF ACADEMIC RESEARCH IN BUSINESS AND SOCIAL SCIENCES Vol. 10, No. 9, 2020, E-ISSN: 2222-6990 @ 2020 HRMARS

such as good roads, healthcare facilities, and provision of schools among others to the citizenry, tax revenue have been so instrumental in Nigeria.

Tax revenue or taxation generally is defined as a compulsory and statutory levy imposed by the government on the income of the citizens, profits of firms, and on consumption of final goods. Further description of tax according to Anyanwu (1997) is that tax are compulsory transfer or payment (or occasionally of goods and services) from private individuals, institutions or groups to the government. As a compulsory, statutory, and obligatory duty of every citizen to the government, it should be understood that these contribution by the tax payers cannot be equal to the expected roles benefits to be enjoyed by the citizens from the government (Nzota, 2007; Onyele and Nwokoacha, 2016). The various forms of tax revenues that the federal government of Nigeria collects through its agency (Federal Inland Revenue Service-FIRS) include Petroleum profit tax which requires all firms engaged in extraction, refining, and distribution of petroleum products in the oil and gas sector and all its affiliates to pay tax, companies income tax which is imposed on the profits made by all firms or companies operating in Nigeria excluding those in the oil and gas sector (Adereti, 2011), value added tax (VAT) which is placed on consumption of final products; value chain at every point of production and consumption of products warrants VAT to be charged on the final user, personal income tax (PIC) which is a direct tax usually based on pay as you earn (PAYE), custom duties which represents taxes levied on imports (and, sometimes, on exports) by the customs authorities of a country to raise state revenue, and/or to protect domestic industries from facing competition of other foreign firms, and excise duty taxes which are levied on locally manufactured goods and services. Among these categories of taxes, non-oil tax revenue include all except petroleum profit tax (PPT). That is, oil tax revenue (OTR) is based on taxes from all operations that pertain to the oil and gas sector, but the non-oil tax revenue (NOTR) sources are made up of all the other categories mentioned above.

It has been remarked largely that the real sectors of the economy of Nigeria which include the agriculture and the industry have significantly contributed to the growth of the economy in the 1960s and 1970s, as such, the source of foreign exchange earning was predominantly based on agricultural commodity export which accounted for about $50 \%$ of the gross domestic product (GDP), $90 \%$ of foreign exchange earnings, employed more than $75 \%$ of the labour force and produced over $70 \%$ of total food consumption (Reynolds, 1966; Chukwuka, et al. 2013; and Gbaiye, et al. 2011). During these periods, most of the well-built infrastructures in Nigeria from the proceeds of the output growth from the real sectors of the economy are still having lasting impacts on the economy.

The major point of worries in the current times is that since the discovery of crude oil and the oil boom of 1970s, the revenue attention of successful government have shifted to crude oil while the real sectors are marked with consistent absence of attention to revive these sectors whereas, heavy reliance is now placed on OTR and less on NOTR. It should be recalled however that since oil have dominated the revenue source of Nigeria for more than three decades now, the growth process warranted through the proceeds of OTR seem to be lopsided in such a way that they are non-inclusive or being pro-poor. The type of growth that creates economic opportunity for all segments of the population and distributes the dividends of increased prosperity is the type that is inclusive and growth that enhances the closing of the gap between the rich and poor is termed pro-poor (World Bank, 2009).

With the new global trend on the pursuit of inclusive or pro-poor growth through the Sustainable Development Goals (SDGs), it has been largely stressed that mere increase in the output/GDP without transforming the citizens thereof is a condition of immiserizing growth or pauperizing growth 
INTERNATIONAL JOURNAL OF ACADEMIC RESEARCH IN BUSINESS AND SOCIAL SCIENCES Vol. 10, No. 9, 2020, E-ISSN: 2222-6990 @ 2020 HRMARS

(Ojameruaye, 2014) or non-pro-poor growth. Unfortunately, this type of jobless growth seems to persist in Nigeria despite increases in OTR. One of the reasons for this unhandsome development would not be unconnected with the fact that revenue from oil have decreased in the recent times as a result of high volatility of oil prices consequent on fluctuation of oil prices in the international market (see figure 2.1). Again, oil is non-renewable; its operation is marked with increasing environmental impacts and the current shift of the attention to greenhouse economy to make energy production and consumption sustainable and environmental friendly is making heavy reliance on oil revenue unsustainable already. Thus, it is timely to turn the tides to the direction of NOTR to be able to harness the potential of the real sectors (agriculture, manufacturing, and the service sectors) in Nigeria.

From the foregoing, it can be identified that the sources of NOTR are more than OTR and majority of the population or the labour force work in the real sectors than the oil sector. However, the low level of tax revenue, especially the NOTR in Nigeria can be attributed to poor tax administration and incidence of tax evasion and avoidance among tax payers (individuals and corporate bodies) that have led to fiscal deficit and epileptic economic performance (Adeniyi, 2012; Akintoye, 2013). Therefore, in view of the existing paradox that OTR dominates the revenue structure of Nigeria and issues of jobless, non-inclusive and pro-poor growths abound, seemingly inconclusive questions that come to mind include: what is the trend of OTR and NOTR in Nigeria? What are the relative impacts of OTR and NOTR in Nigeria? Which of these revenue sources is more inclusive and pro-poor, and which of them can be leveraged for sustainable development in Nigeria? Any genuine policy attempt to increase revenue beyond oil in Nigeria cannot overtly neglect addressing these empirical concerns. Although various authors have attempted addressing similar questions raised. For instance, Nwaru (2015) did a comparative analysis of the impacts of OTR and NOTR on Nigeria's GDP for the period of 2004-2013 with annual data. This author however did not examine the time series properties of the data to ensure accurate and valid policy outcome. Similarly, Ogbonna, et al. (2012) employed time series data from 1994 to 2004 and found that tax reform increased government revenue. This author did not separate the analysis to OTR and NOTR.

Despite the existing studies, this study found it research-wise to contribute to knowledge by addressing the research questions raised. Thus, the point of departure of this current paper from the existing ones is that it addresses the this paper using quarterly data ranging from the first quarter of 2011 to the first quarter of 2016 sourced directly from the database of Federal Inland Revenue (based on availability) were used. Again, data on GDP measured per active labour force were sourced for Nigeria from the World Development Indicators to be able to measure growth that is inclusive using a fully modified ordinary least squared approach to cointegrating equations. The remainder of this paper is laid out as followed. Aside this introduction, section two give brief stylized facts about the trend of revenue generation and economic growth rate in Nigeria. Section three briefly reviewed the literature, methodology of the study is detailed in section four, and section five shows the empirical results and the findings while section six concludes the study.

\section{Some Stylized Facts about Tax Revenue and Economic Growth in Nigeria}

Tax Revenue Trend in Nigeria

As noted earlier, tax revenue in Nigeria is divided into oil and non-oil. Revenue dependency of Nigerian government drifted from the real sectors such as agriculture and industry with the first commercial discovery of oil in 1957 by shell which started production in 1958 at Oloibiri in the Niger 
INTERNATIONAL JOURNAL OF ACADEMIC RESEARCH IN BUSINESS AND SOCIAL SCIENCES Vol. 10, No. 9, 2020, E-ISSN: 2222-6990 @ 2020 HRMARS

Delta (Anyanwu, 1997). Further licenses were given to different companies for oil prospecting and gradually, this hydrocarbon, and non-renewable substance (crude oil) took the lead in Nigeria and revenue reliance was fully on oil. Within the first quarter of 2011 and 2016, the trend of oil and nonoil tax revenue of Nigeria is charted in figure 2.1. It is glaring that OTR took the lead until 2013 while NOTR sagged behind. But the trend is changing nowadays.

Figure 2.1: Trend of Oil \& non-oil tax revenue in Nigeria (2011-2016)

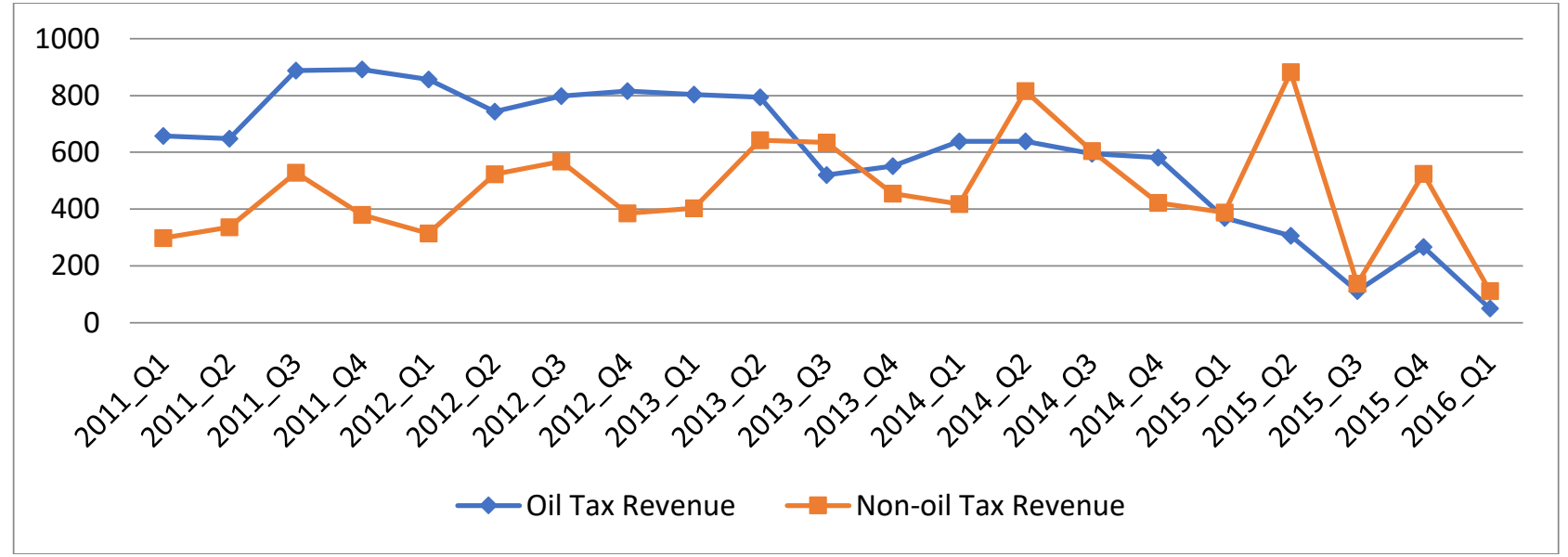

Source: Computed by the author from FIRS Database, 2017

The trend of the chart above have shown that right from the third quarter of 2013 till the first quarter of 2016, the rate of NOTR outpaced that of OTR. Specifically, within the second quarter of 2015, NOTR surged to 882 billion naira while that of OTR was 306.2 billion. Persistent fluctuations generally characterized the trajectory of the flows of both OTR and NOTR. However, the growth of NOTR is outpacing that of OTR in the recent times. In fact, the revenue from oil remain unsustainable in the recent times, and this could be explained by the fact that the OTR is subject to global volatility in the price of crude, thus, there is need for optimization of NOTR to make the growth of the economy sustainable.

\section{Output Growth Rate in Nigeria}

The expectation is that since tax revenue is a central component for financing the economy, the rate of growth of the economy can be attributed to amount of revenue obtained and the level of fiscal disciplines. Although it is shown that the level of output growth (growth rate of GDP) for Nigeria is not at wide variance from the rate for the entire Sub-Saharan Africa (SSA), ECOWAS, and the world as shown in Table 2.1, but evidence from figure 2.1 disappointedly revealed that poverty incidence is high in Nigeria despite such output growth. 
INTERNATIONAL JOURNAL OF ACADEMIC RESEARCH IN BUSINESS AND SOCIAL SCIENCES Vol. 10, No. 9, 2020, E-ISSN: 2222-6990 @ 2020 HRMARS

Table 2.1 Average GDP growth rate of ECOWAS, its sub-regions and the world (1974-2015)

\begin{tabular}{|c|c|c|c|c|c|c|c|}
\hline $\begin{array}{l}\text { Country } \\
\text { Name }\end{array}$ & $\begin{array}{l}1974- \\
1979\end{array}$ & $\begin{array}{l}1980- \\
1985\end{array}$ & $\begin{array}{l}1986- \\
1991\end{array}$ & $\begin{array}{l}1992- \\
1997\end{array}$ & $\begin{array}{l}1998- \\
2003\end{array}$ & $\begin{array}{l}2004- \\
2009\end{array}$ & $\begin{array}{l}2010- \\
2015\end{array}$ \\
\hline Nigeria & 3.67 & $\begin{array}{c}- \\
1.45\end{array}$ & 1.11 & 1.82 & 4.51 & 10.9 & 5.94 \\
\hline ECOWAS & 3.42 & 1.37 & 1.62 & 3.47 & 4.14 & 4.84 & 5.32 \\
\hline SSA & 3.18 & 1.54 & 1.59 & 2.17 & 3.16 & 5.47 & 4.68 \\
\hline World & 3.31 & 2.56 & 3.29 & 2.78 & 2.81 & 2.53 & 2.90 \\
\hline
\end{tabular}

Source: Authors' computation from online database of the World Development Indicators (WDI) 2016

It can be seen from the table above that the period before the structural adjustment programme (SAP), that is between 1980-1985, the growth rate of output in Nigeria was negative, the trend change positively and the period of the global financial crisis (2004-2009), output growth of Nigeria averaged $10.9 \%$. This mean that Nigeria was not affected like other countries during the crises, this growth could not be far from oil revenue, but the growths therefrom seem to be non-inclusive.

\section{Some Poverty Profile in Nigeria}

Undoubtedly, for three decades now, it can be observed that as Nigerian economy is paradoxically growing, the proportion of Nigerians living in poverty is increasing every year as shown in Figure 2.2. The proportion of the population living below the poverty line increased significantly from 1980 to 2010.

Fig. 2.2: Nigeria Estimated Population and Poverty Incidence (1980- 2010)

- Poverty Incidence (\%) Estimated Population (Million) - Population in poverty (Million)

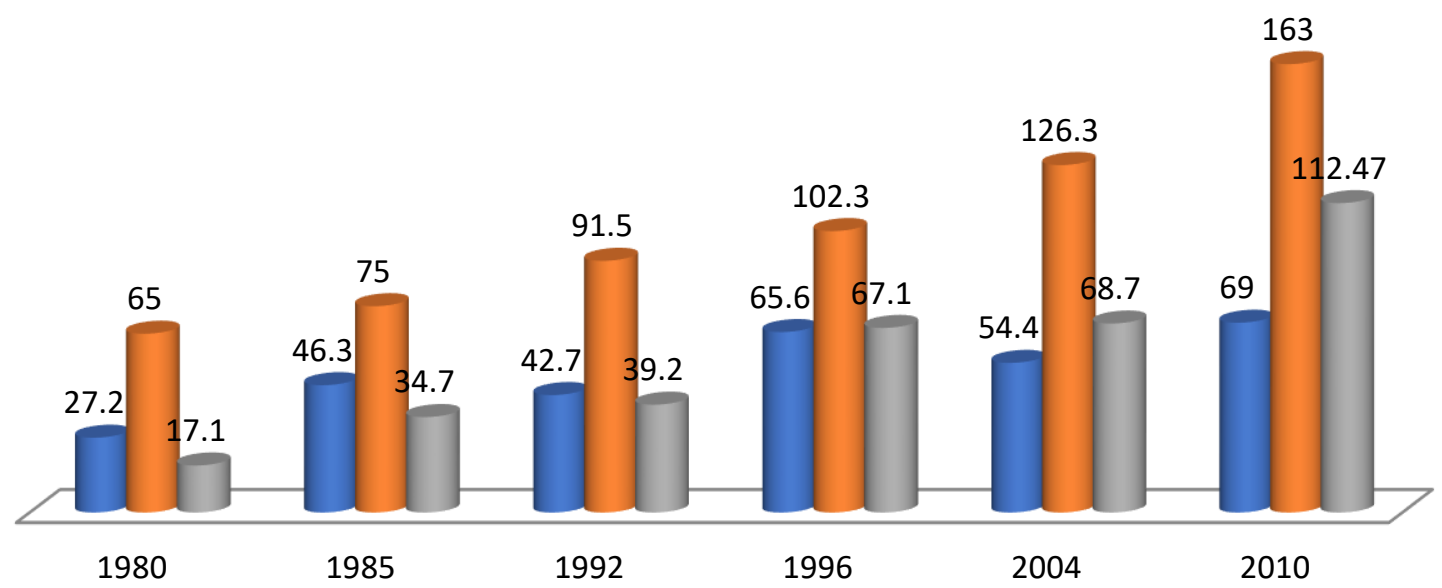

Source: Adopted from the work of Owuru \& Farayibi (2016) on Examining Fiscal Policy-Poverty Reduction Nexus in Nigeria. https://mpra.ub.uni-muenchen.de/74184/

With such increasing trend of population in poverty, the trend will likely continue to the current times, and the concern now is that is it OTR which hitherto dominates the revenue structure of 
INTERNATIONAL JOURNAL OF ACADEMIC RESEARCH IN BUSINESS AND SOCIAL SCIENCES Vol. 10, No. 9, 2020, E-ISSN: 2222-6990 @ 2020 HRMARS

Nigeria that could not transformed the economy? Now can such pro-poor growth dynamics be changed in view of the seeming rise in NOTR as figure 2.1 showed? In the methodological and empirical results (which this study will show) the possibility of leveraging on NOTR for inclusive and pro-poor growth in Nigeria will be revealed.

\section{Brief Literature Review}

Theoretical Review

There is no settlement in various theories that explain the connection between tax and government fiscal responsibilities. First, the cost of service theory (CST) holds that tax is synonymous to price paid for a given commodity by consumer. In this case, the citizens are expected to bear the cost of any services rendered by the government to them. That is, the cost incurred by government in providing certain services to the people must collectively be met by the people who are the ultimate receivers of the service (Ojong et al., 2016). The perspective of this theory cannot be wholly applied because; the implication is that the citizens should be responsible for all social and economic services provided by the state to them. In this case, tax could not be said to be compulsory, and if a citizen does not consume a given service of the government, taxes should not be paid.

Secondly, benefit received theory (BRT) of tax is also similar to cost of service theory. This According to this theory, the provision of social services by the state to the citizens is statutory and that the citizens are in turn expected to pay tax that is equivalent to the benefit received from the government (Anyanfo, 1996). The contention here is that can citizens' tax rate be equivalent to all the socioeconomic benefits that they will drive from the socially provided amenities in the state? The idea here should be that tax should just be a sense of responsibility of every citizen to the state, but not that tax paid should be benefit equivalent. Thirdly, ability to pay theory (ATP) of tax sees tax liability in its true form-compulsory, but based on ability to pay. That is the paying capacity of the citizen based on income and profit from the business should be the determinant of the rate of tax to be paid (Anyanfo, 1996).

Fourthly, socio-political theory (SPT) of taxation as advocated by Adolph Wagner is that the social and political objectives of the state should be the determinant of tax rates, hence, it is the societal consideration that should inform the expected rate of tax that the citizens should pay (Ayuba, 2014). Going by this however, the state may have charged or increase tax rates that the citizens may not be able to pay. In fact, cases of tax evasion and avoidances are not far from the fact that many taxable adults cannot pay taxes consistently due to economic hardships.

Last, but not the least is the expediency theory (EXPT) of tax. According to this theory, tax rates that cannot be practically collected by the state should be avoided. It will be useless to have a tax which cannot be levied and collected efficiently. This theory should be put in consideration by tax administrators in Nigeria so that there should be economics in tax collection in such a way that the cost of collecting tax should not be more than the amount collected for the government.

\section{Empirical Review}

To be able to contribute to knowledge, the existing level of knowledge in the area of tax revenue and growth for Nigeria that other researchers have found are reviewed in this section. Ojong, et al. (2016) empirically assessed the nexus between tax revenue and economic growth in Nigerian economy with the use of Ordinary least square (OLS) in multiple regression and found that significant relationship between petroleum profit tax and the growth of the Nigeria economy. Also, the study found 
INTERNATIONAL JOURNAL OF ACADEMIC RESEARCH IN BUSINESS AND SOCIAL SCIENCES Vol. 10, No. 9, 2020, E-ISSN: 2222-6990 @ 2020 HRMARS

significant relationship between non-oil revenue and the growth of the Nigeria economy but on the part of company tax and economic growth, no significant relationship was found.

Similarly, between 1993 and 2012, Ayuba (2014) employed time series data to analyze the impact of tax revenue on economic growth in Nigeria within the framework of OLS and found from the results that tax revenue exerted a positive impact on economic growth in Nigeria. As part of the empirical investigation to identify incidence of tax evasion and avoidance, Adeniyi (2012) studied the effect of tax administration on revenue generation to the Enugu state government. By using both survey and secondary data, this author found that there was widespread incidence of tax evasion and avoidance in Enugu state due to inadequate, ineffective and inefficient tax administration. Okafor (2012) explored the linkage between one of the components of NOTR (income tax) and economic growth for the period of 1981-2007 using OLS and found that there is no significant relationship between federally collected tax revenue and the GDP in Nigeria. For countries in the organization for economic co-operation and development (OECD), Tosun and Abizadeh (2005) examined economic growth effects of tax changes from 1980 to 1999 reveal that personal and property taxes responded positively to economic growth, while goods and services taxes showed declining effects.

There is plethora of empirical assertions that lay credence to the fact that tax revenue, especially NOTR is a stable source of government revenue and that if all tax administrative inefficiencies are avoided, the pools of tax fund will suffice and that the government may not need external borrowing to finance the economy (Phillips, 1973; Omorogiuwa, 1981; Aguolu, 2004).

\section{Data and Methodology}

This study adopts econometric approach to examine the potency of both OTR and NOTR in contributing to inclusive and pro-poor growth in Nigeria. To achieve this, the collected data from FIRS, Central Bank of Nigeria (CBN) and WDI are analyzed. The various methodologies followed and the results are shown in this section.

\section{Model Specification}

It is identified that for growth to be inclusive, and by extension pro-poor, the proceeds (output) should benefit the labour. Thus, a simple regression model in which GDP per person employed (GDPPPE) sourced from WDI is used as the dependent variable is econometrically specified. The explanatory variables are the OTR and NOTR.

$$
\log G D P P P E_{t}=a_{0}+a_{1} \log O T R_{t}+a_{2} \log N O T R_{t}+\varepsilon_{t}
$$

Where GDPPPE is gross domestic product divided by the labour force, OTR is oil tax revenue, and NOTR is non-oil tax revenue as previously explained. $\varepsilon$ is the error term that captures all other random variables that can help determine changes in GDPPPE, while t represents the time series dimension of the model. The theoretical or apriori expectation is that both OTR and NOTR will contribute significantly to increase in output per labour. In this case, the growth outcome can be said to be inclusive (World Bank, 2009, 2010; AfDB, 2011; and Stuart, 2011).

\section{Methodology}

The methodological procedures here include the test for stationarity, cointegration test, fully modified OLS (FMOLS), and the Granger causality test. These tests were applied on quarterly data of the variables in the specified model in equation (4.1) covering the period of 2011-2016. Although the time spans seem so short, but by disaggregating them into four quarter for each year, the data points 
INTERNATIONAL JOURNAL OF ACADEMIC RESEARCH IN BUSINESS AND SOCIAL SCIENCES Vol. 10, No. 9, 2020, E-ISSN: 2222-6990 @ 2020 HRMARS

were 24. Again, the choice of this period is underscored by the fact that recent democratic regimes in Nigeria have demonstrated commitment to governance, yet issues of lopsidedness in institutional will to transform the economy have been expressed from various stakeholders and the common publics. With this short period, a fully modified OLS was used after ascertaining the unit root properties of the data. According to Hansen and Phillips $(1990,1991)$ FMOLS produces efficient estimates than OLS for I (1) variables. ${ }^{1}$

\section{Empirical Results}

\section{Unit Root Results}

The data were tested for unit root, i.e. if there are stationary. Augmented Dickey Fuller (ADF) test proposed by Dickey and Fuller (1981) was applied and it was found that the variables (GDPPPE, OTR and NOTR) were differenced stationary. That is, there were potentially non-stationary at level, but after differencing them once, they integrated at the first difference, I (1). This result is shown below.

Table 5.1 ADF Unit Root Test

\begin{tabular}{|c|c|c|c|c|c|}
\hline Variable & \multicolumn{2}{|c|}{ Critical Value } & ADF test statistic & P-Value & Order of Integration \\
\hline \multirow{3}{*}{ OTR } & $1 \%$ level & -3.831511 & \multirow{3}{*}{-4.736262} & \multirow{3}{*}{$0.0015^{*}$} & \multirow{3}{*}{ I (1) } \\
\hline & $5 \%$ level & -3.029970 & & & \\
\hline & $10 \%$ level & -2.655194 & & & \\
\hline \multirow{3}{*}{ NOTR } & $1 \%$ level & -4.616209 & \multirow{3}{*}{-13.56993} & \multirow{3}{*}{$0.0000 *$} & \multirow{3}{*}{ I (1) } \\
\hline & $5 \%$ level & -3.710482 & & & \\
\hline & $10 \%$ level & -3.297799 & & & \\
\hline \multirow{3}{*}{ GDPPPE } & $1 \%$ level & -4.667883 & \multirow{3}{*}{-4.862728} & \multirow{3}{*}{$0.0072 *$} & \multirow{3}{*}{ I (1) } \\
\hline & $5 \%$ level & -3.733200 & & & \\
\hline & $10 \%$ level & -3.310349 & & & \\
\hline
\end{tabular}

Note: ${ }^{*}$ denotes rejection of the null hypothesis at $1 \%$ level of significance. The null hypothesis is that each variable exhibits a unit root (stationary)

Source: Author's computation from Eview 9.

Since all the variables are significant, the null hypothesis of stationarity for each of the variable is rejected, and by implication, the data generating process of the variables is non-stationary, but with the method of differencing suggested by ADF, the variables were stationary at order I (1). This therefore shows that the variable can cointegrate and exhibit a long run impact or relationship on one another. Thus, the result for the cointegration is presented.

\subsection{Result of the Johansen Cointegration Test}

Having established that the series can be cointegrated because of their integration of order 1 , the Johansen cointegration test was applied and the result is presented in Table 5.2 with its implied interpretations.

1 For detail derivations of the algebra for the FMOLS, readers should consult Hansen and Phillips (1991), and Phillips (1991). FMOLS provides optimal estimates of cointegrating regression and it help overcome account or handles the possibility of serial correlation and endogeneity effects that can 
INTERNATIONAL JOURNAL OF ACADEMIC RESEARCH IN BUSINESS AND SOCIAL SCIENCES Vol. 10, No. 9, 2020, E-ISSN: 2222-6990 @ 2020 HRMARS

Table 5.2 Johansen Cointegration Test Results

\begin{tabular}{|c|c|c|c|c|}
\hline \multicolumn{5}{|c|}{ Unrestricted Cointegration Rank Test (Trace) } \\
\hline \multicolumn{2}{|l|}{ Hypothesized } & Trace & \multicolumn{2}{|l|}{0.05} \\
\hline No. of $\mathrm{CE}(\mathrm{s})$ & Eigenvalue & Statistic & Critical Value & Prob.** \\
\hline None $*$ & 0.643049 & 39.35996 & 29.79707 & 0.0030 \\
\hline At most $1 *$ & 0.516205 & 19.78696 & 15.49471 & 0.0106 \\
\hline At most $2 *$ & 0.270449 & 5.991192 & 3.841466 & 0.0144 \\
\hline \multicolumn{5}{|c|}{ Unrestricted Cointegration Rank Test (Maximum Eigenvalue) } \\
\hline Hypothesized & & Max-Eigen & 0.05 & \\
\hline No. of CE(s) & Eigenvalue & Statistic & Critical Value & Prob.** \\
\hline None & 0.643049 & 19.57300 & 21.13162 & 0.0814 \\
\hline At most 1 & 0.516205 & 13.79577 & 14.26460 & 0.0592 \\
\hline At most $2^{*}$ & 0.270449 & 5.991192 & 3.841466 & 0.0144 \\
\hline \multicolumn{5}{|c|}{$\begin{array}{l}\text { Both Trace and Max-eigenvalue tests indicate } 3 \text { cointegrating } \\
\text { equations at the } 0.05 \text { level. * denotes rejection of the hypothesis at } \\
\text { the } 0.05 \text { level }\end{array}$} \\
\hline
\end{tabular}

Source: computed by the author from EViews 9.

The Cointegration result above indicates that there are three cointegrating equations or vectors among the series. In other words, there is evidence of stable long-run relationship among them and so it is therefore possible to avoid both the spurious and inconsistent regression problems which otherwise would occur with regression of non-stationary data series. The existence of cointegrating relationships among these I (1) variables implies that OTR and NOTR are potential determinants of inclusive growth in Nigeria over the selected years. Hence, the magnitudes of the impact of these regressors on GDPPPE are shown in the results obtained from the FMOLS in Table 5.3.

5.3 Results for the FMOLS

\begin{tabular}{crrrr}
\hline \hline Variable & Coefficient & Std. Error & t-Statistic & Prob. \\
\hline \hline LOG(OTR) & -0.100587 & 0.010365 & -9.704700 & $0.0000^{*}$ \\
LOG(NOTR) & 0.045265 & 0.015245 & 2.969239 & $0.0086^{*}$ \\
C & 10.21555 & 0.069911 & 146.1217 & $0.0000^{*}$ \\
\hline \hline R-squared & 0.828406 & Mean dependent var & 9.864005 \\
Adjusted R-squared & 0.808219 & S.D. dependent var & 0.062195 \\
S.E. of regression & 0.027237 & Sum squared resid & 0.012611 \\
Long-run variance & 0.000639 & & & \\
\hline \hline
\end{tabular}

Note: * denotes rejection of the null hypothesis at 1\% level of significance. The null hypothesis is that these variables are not significant determinants of inclusive growth.

Source: computed by the author from Eview 9.

The results from the FMOLS examined the long run impact of OTR and NOTR on inclusive growth (output/labour force). The adjusted coefficient of the determination of the model (Adjusted $\mathrm{R}^{2}$ ) which 
INTERNATIONAL JOURNAL OF ACADEMIC RESEARCH IN BUSINESS AND SOCIAL SCIENCES Vol. 10, No. 9, 2020, E-ISSN: 2222-6990 @ 2020 HRMARS

account for the overall explanatory power of the model after adjusting for loss in the degree of freedom performs well at $80.8 \%$. By implication, both OTR and NOTR approximately accounted for $81 \%$ variations in economic growth that is inclusive. In addition, the long run variance of the model is small, implying that these variables (revenue) are relevance in determining inclusive growth if they are efficiently used.

In terms of the performance of individual parameters in the FMOLS model, it can be seen that it is the non-oil tax revenue that showed positive impact on inclusive growth. Specifically, a $1 \%$ increase in NOTR is by expectation will lead 4.5 or approximately $5 \%$ increases in inclusive growth. On the contrary, the coefficient OTR signed negatively and by implication, a $1 \%$ increase in OTR has the potential of causing non-inclusive growth for about $10.1 \%$ for the period of time covered in this study. Thus, the result showed, overall that NOTR has more potential for enhancing sustainable economic growth that will be inclusive and pro-poor in outlook.

Again, to verify the robustness of the FMOLS results, a Wald test is shown in Table 5.4.

Table 5.4: Wald Test

\begin{tabular}{lccc}
\hline \multicolumn{4}{l}{ Equation: FMOLS } \\
\hline \hline Test Statistic & Value & $\mathrm{df}$ & Probability \\
\hline t-statistic & -62.62728 & 17 & $0.0000^{*}$ \\
F-statistic & 3922.176 & $(1,17)$ & $0.0000^{*}$ \\
Chi-square & 3922.176 & 1 & $0.0000^{*}$ \\
\hline \hline
\end{tabular}

Null Hypothesis: $\mathrm{C}(1)=1$

Null Hypothesis Summary:

\begin{tabular}{lcc}
\hline \hline Normalized Restriction (=0) & Value & Std. Err. \\
\hline \hline$-1+C(1)$ & -0.954735 & 0.015245
\end{tabular}

Restrictions are linear in coefficients.

Note: * denotes rejection of the null hypothesis at 1\% level of significance.

Source: computed by the author from Eview 9.

From the results, the null hypothesis is rejected at $1 \%$ level of statistical significance by the T-statistic, F-statistic, and the Chi-square distribution. The null hypothesis implies that the model of FMOLS has a constant, but having tested for unit root and found cointegration through the Johansen test, the Wald test further help authenticate the fact that the variables are differenced stationary and has long run impact on each other. Therefore, the choice of the FMOLS and its results explained above are valid.

The next concern is that which of these categories of revenue granger cause changes in inclusive growth? This lacuna is addressed through the results from the granger causality test as shown below in Table 5.5 . 
INTERNATIONAL JOURNAL OF ACADEMIC RESEARCH IN BUSINESS AND SOCIAL SCIENCES Vol. 10, No. 9, 2020, E-ISSN: 2222-6990 @ 2020 HRMARS

\section{Table 5.5: the Granger Causality Test}

Pairwise Granger Causality Tests

Date: 08/30/17 Time: 08:20

Sample: 2011Q1 2016Q1

Lags: 2

\begin{tabular}{lccc}
\hline \hline Null Hypothesis: & Obs & F-Statistic & Prob. \\
\hline \hline & & & \\
OTR does not Granger Cause GDPPPE & 19 & 2.62107 & 0.1079 \\
GDPPPE does not Granger Cause OTR & & 5.25692 & $0.0198^{*}$ \\
\hline \hline & \multirow{2}{*}{19} & 0.61780 & 0.5532 \\
NOTR does not Granger Cause GDPPPE & & 5.58141 & $0.0165^{*}$ \\
GDPPPE does not Granger Cause NOTR & 19 & 1.87848 & 0.1894 \\
\hline \hline NOTR does not Granger Cause OTR & & 1.91359 & 0.1842 \\
OTR does not Granger Cause NOTR & & & \\
\hline \hline
\end{tabular}

Note: * denotes rejection of the null hypothesis at $10 \%$ level of significance.

Source: computed by the author from Eview 9.

The result showed that at $10 \%$ level of statistical significance, uni-directional causality was exit between GDPPPE and OTR and it runs from GDPPPE to OTR and not the reverse. Also, at the same level of significance, uni-directional causality ran from GDPPPE to NOTR and not the reverse. No causality exists between OTR and NOTR. The implication of these results is that it is the labour force that really contributes to increase in both Oil and non-oil revenue but these revenues does not lead to changes in inclusive growth over the years. And the issue of no causality between OTR and NOTR is indicative of the fact that there is no complimentary or value chain relationships among various sources of non-oil sectors (real sectors) and the oil and gas sector. This situation of no feedback effects could be responsible for lopsided, non-inclusive and jobless growth in Nigeria.

\section{Conclusions}

It evidence from the analysis so far that both oil and non-oil revenue are significant for sustainable public finance in Nigeria. However, OTR has been the main stay of revenue for Nigeria since the discovery of the oil in commercial quantity. In the recent times however, there have been evidence that NOTR is surging high and in the nearest time it can outperform OTR significantly considering that OTR is subject to volatility and fluctuations in prices. Having found that OTR has evidence of negative impact on inclusive growth than NOTR, policy focus should be on economic and revenue diversification from oil in order to achieve sustainable inclusive growth in Nigeria. Again, value chainbased economic diversification is recommended so that all the sectors of Nigerian economy can complement each other. For instance, increase if activities in the oil sector are diversifying extensively, agro-chemical industries in Nigeria will not suffer and increased non-oil revenue can be obtained. 
INTERNATIONAL JOURNAL OF ACADEMIC RESEARCH IN BUSINESS AND SOCIAL SCIENCES Vol. 10, No. 9, 2020, E-ISSN: 2222-6990 @ 2020 HRMARS

\section{References}

Adeniyi, A. R. (2012), The Effect of Tax Administration on Revenue Generation in Enugu State.

(A Case Study of the State Board of Internal Revenue Enugu State). Faculty of Management and Social Sciences, Caritas University Amorji- Nike Enugu State.

Adereti, S. A., Sanni, M. R., Adesina, J. A. (2011), Value Added Tax and Economic Growth of Nigeria. European Journal of Humanities and Social Sciences, vol.10, pg 456-471.

AfDB. (2011), Africa: Inclusive Growth, Occasional Series, Vol. 1, Issue 1, September.

Aguolu, O. (2004), Taxation and Tax Management in Nigeria, 3rd Edition, Enugu: Meridan Associates.

Akintoye, I. R., Tashie, G. A. (2013), The Effect of Tax Compliance on Economic Growth and Development in Nigeria, West-Africa. British Journal of Arts and Social Sciences 11: 222-231.

Anyanfo, A. M. O. (1996), Public Finance in Developing Economy: The Nigeria Case.Enugu: B\&F Publication

Anyanwu, J. C. (1997), Nigerian Public Finance. Joannne Educational Publishers, Onitsha. Ayuba, A. J. (2014), Impact of Non-oil Tax Revenue on Economic Growth: The Nigerian Perspective. International Journal of Finance and Accounting 3: 303-309.

Chukwuka, O. I., Uwajumogu, N. R., Chijioke, G., Ebele, S. (2013), Oil Exploitation and Agricultural Commodity Export in Nigeria: An Empirical Evaluation of the Extent and Impact of the Dutch Disease. IOSR Journal of Humanities and Social Science (IOSR-JHSS) 14: 01-09.

Dickey, D. A., Fuller, W. A. (1981), "Likelihood Ratio Statistics for Autoregressive Time Series with a unit Root" Econometrical 49.

Gbaiye, G. O., Ogundipe, A., Osabuohien, E., Olugbire, O. O., Adeniran, O. A. (2011), Agricultural Exports and Economic Growth in Nigeria (1980-2010). Journal of Economics and Sustainable Development 4: 1-4.

Hansen, B. E., Phillips, P. C. B. (1991), Estimation and inference in models of cointegration: A simulation study. Advances in Econometrics, vol.8, pg 225-248.

Nwaru, C. K. ( 2015),Tax Revenue Performance: A Comparative Study of Oil and Non-oil Tax Revenue on Nigeria's GDP. Federal Inland Revenue Service, Abuja HQ.

Nzotta, S. (2007) Tax Evasion Problems in Nigeria: A Critique. Nigeria Account, vol. 40: 40-43. Ogbonna, G.N., Appah, E. (2012), Impact of Tax Reforms and Economic Growth of Nigeria: A Time Series Analysis. Current Research Journal of Social Sciences, Vol.4. No.1.pg.62-68.

Ojameruaye, E. (2014), Public spending and Economic Growth in Nigeria. A paper presented at the Nigerian Economic Society (NES) Conference, Sheraton Hotel Abuja, Nigeria.

Ojong, M. C., Anthony, O., and Arikpo, F. O. (2016), The Impact of Tax Revenue on Economic Growth: Evidence from Nigeria. IOSR Journal of Economics and Finance 7: 32-38.

Okafor, R. G. (2012), Tax Revenue Generation and Nigerian Economic Development. European Journal of Business and Management, Vol 4, No.19.

Omorogiuwa, P. A. (1981). Tax Administration in Nigeria. A Paper presented at the First National Symposium on Taxation, Lagos October.

Onyele, K. O., Nwokoacha, E. B. (2016), Sources of Public Funds and Economic Prosperity: The Nigerian Case. Journal of Business and Financial Affair, Vol. 5, No. 215.

Owuru, J. E., Farayibi, A. (2016), Examining Fiscal Policy-Poverty Reduction Nexus in Nigeria. 
INTERNATIONAL JOURNAL OF ACADEMIC RESEARCH IN BUSINESS AND SOCIAL SCIENCES

Vol. 10, No. 9, 2020, E-ISSN: 2222-6990 (C) 2020 HRMARS

Econometric Modelling: Macroeconomics e-Journal, Vol. 6, No. 165

Philips, P. C. B. (1991a), Optimal Inference in Cointegrating System. Econometrica, vol.55, pg 277-301

Philips, A. O. (1973), A Note on the Determinants of Income Tax Evasion. Nigerian Journal of Public Affairs, Vol. 1. No 1..

Reynolds, L. C. (1966), Peasant Agriculture and Economic Growth in Nigeria. The Economic Growth Center, Yale: Yale University.

Stuart, E. (2011), Making Growth Inclusive: Some Lessons from Countries and the Literature, Oxfam Research Report, April

Tosun, M. S., Abizadeh, S. (2005), Economic growth and tax components: An analysis of tax change in OECD. Applied Economics. Vol. 37, pg. 2251-2263.

Wong, J. D. (2004), The Fiscal Impact of Economic Growth and Development on Local Government Revenue Capacity. Journal of Public Budgeting, Accounting \& Financial Management 16: 413-423.

World Bank. (2009), "What is Inclusive Growth", World Bank, Washington DC.

World Bank. (2010), Africa Development Indicators 2008/2009 "Youth Employment in Africa:

The Potential, the Problem, the Promise", World Bank, Washington DC. 